\title{
THE RELATIONSHIP BETWEEN NATIONAL PARKS AND LOCAL GOVERNMENTS IN THE AREA OF TOURISM DEVELOPMENT IN POLAND: COLLABORATION, OPPORTUNITIES AND CHALLENGES
}

\begin{abstract}
The purpose of the paper is to discuss the scope and quality of collaborative efforts between national parks and local governments in the area of tourism development. The research procedure is based on the questionnaires received from all 23 national parks in Poland, which welcome a total of about 11 million tourists per year. The largest number of park and local government decisions made concern promotional efforts and the development of tourist infrastructure mostly walking trails. Most national parks (61\%) do suggest that tourism development conflicts with the mission of national parks. The research results may help better understand the relationship between national parks and local governments and may help evaluate what is expected of government officials.
\end{abstract}

Keywords: protected areas, local governments, tourism management, Poland

\section{Streszczenie}

\section{Parki narodowe i samorządy terytorialne a działania na rzecz rozwoju turystyki w Polsce: współpraca, możliwości oraz wyzwania}

Celem opracowania jest analiza zakresu i ocena współpracy parków narodowych z władzami samorządowymi na rzecz rozwoju turystyki. W artykule zaprezentowano diagnozę wspólnie podejmowanych działań z zakresu turystyki nakreśloną z perspektywy wszystkich (23) parków narodowych w Polsce. Obszary te odwiedza rocznie około 11 mln turystów. Najwięcej wspólnie podejmowanych z samorządem działań z zakresu turystyki dotyczy działań promocyjnych. Następnie wskazywano na rozwój infrastruktury turystycznej (głównie szlaków). 61\% parków wskazuje na istnienie konfliktów związanych z rozwojem turystyki i jednocześnie proponuje, jak rozwiązać sytuacje sporne. Zaprezentowane badania mogą pomóc w pełniejszym rozpoznaniu relacji i zbadaniu oczekiwań przedstawicieli parków wobec władz samorządu 
terytorialnego, a w konsekwencji nakreśleniu dróg wiodących do ulepszenia wspólnie prowadzonych działan.

Słowa kluczowe: parki narodowe, samorządy terytorialne, zarządzanie turystyką, Polska

\section{Introduction}

National parks are very unique tourist destinations that draw large numbers of tourists thanks to their natural attractions, but also need to limit what tourists can do while visiting. This does include limitations due to the protective mission of national parks, which must prioritize the protection of the natural environment over all forms of human activity including tourism. The principles of sustainable development dictate that national parks require the care of both local area residents and tourists, and the benefits associated with national parks should also be available to both local area residents and tourists. Protected area-based tourism has many stakeholders, for example: protected area planners and managers, protected area volunteers, protected area visitors, protected area employees, local community, landowners (in and around the area), residents (in and around the area), resource extraction interests, government ministries, allied and sometimes competing government agencies, private sector, non-governmental organizations, environmental groups, economic development organizations, concessionaires, licensees and permit holders, hospitality industry, tour operators, destination marketing/management organizations, educational institutions, research bodies, media [Leung et al., 2014]. It is important to note that the individual goals of the above-listed entities may vary. Local as well as regional leadership is needed to lead efforts to resolve potential conflicts of interest. This leadership should be provided by local government officials. This paper attempts to help identify stakeholder interests from the perspective of national parks - with a special focus on the relationship with local governments at the commune, county, and provincial levels. This is naturally a reference to local governments that manage administrative regions featuring entire national parks or parts of national parks. This paper covers all 23 national parks in Poland, most of them are found in the southern part of the country - in mountainous areas characterized by the highest environmental and landscape value in Poland. The focus of the paper is the in-depth analysis of joint initiatives affecting the tourism industry as well as situations that tend to yield conflict between various parties. This discussion serves as the background for solutions proposed herein and is designed to address specific issues. The desired outcome is improved coordination of projects associated with the concept of sustainable development. It is the purpose of this paper to analyze the extent and value of collaboration between national parks and local governments in Poland in the realm of tourism development. 


\section{Theoretical background}

\section{I. National parks and local governments}

National parks provide the greatest degree of environmental protection in Poland and are one of ten different forms of environmental protection in the country. A national park includes an area that is very unique in terms of environmental, scientific, social, cultural, and educational value. Its surface area must be no less than 1,000 hectares. A national park is designed to help protect all natural features and landscapes present in a given geographic area. In addition, a national park must not function in complete isolation from its parent commune and its local population. National parks and local governments may be described as interdependent entities. The inability to function like a business places a substantial burden on national park managers [Eagles, 2009]. In Poland, the most basic unit of local government is the commune (Polish: gmina). The county is the next higher administrative unit, while the higher regional administrative unit is the province (Polish: województwo), which consists of counties. The Nature Conservation Act of 16 April 2004 (Journal of Laws - Republic of Poland of 2015) states that local governments, business entities, other organizational units, and private individuals are required to care for the natural environment, which is a national treasure and a form of national heritage. At the same time, the government is required to create the right legal, organizational, and financial conditions for the protection of the natural environment. It is also important to note that the national government, research institutions, educational institutions, and the mass media are required to provide educational and information programs as well as to promote environmental protection throughout Poland. Joint coordination of projects by national parks, local governments, and other organizations is not merely a best practice, but also a legal requirement. Polish law states that the director of a national park acts as a regional director of environmental protection within his or her area of jurisdiction. The director is required to work with local governments and other organizations, although the exact form and extent of collaboration are not prescribed by law. A variety of different research disciplines analyze the relationship between local communities and neighboring national parks, also in Poland, for example: Zawilińska, Mika [2013]. However, most papers on this issue tend to be general and do not focus on any single area of collaboration.

\subsection{Tourism as an area for collaboration between national parks and local governments}

The development of tourism requires collaboration between a variety of entities. Any type of partnership in the tourism sector has to involve the following five key dimensions: geographic scale, legal basis, locus of control, 
organizational diversity and size, timeframe [Selin, 1999]. A properly-run partnership usually brings mutual benefits, although difficulties may surface. Certain potential benefits of collaboration in tourism planning are summarized by Bramwell and Lane [2000], who point to a decrease in the negative effects of tourism development, more effectiveness in the development process, and also identify potential problems associated with tourism planning partnerships. Collaboration in protected areas is even more important, where the inclusion of local communities in the tourism planning process is quite essential [Eagles, $\mathrm{McCool}, 2002]$. The lack of research studies on the success rates of tourism development partnerships in protected areas is noted in a report published by Sustainable Tourism Cooperative Research Centre (2008). This key issue was also discussed for the case of Australia, where the need for these partnerships and their potential contribution to sustainable tourism have been identified in a number of recent reports. The following researchers have also analyzed this issue: Selin [1999], Bramwell and Lane [2000], Buckley and Sommer [2001], Kapoor [2001], Pedersen [2002], Saporiti [2006], Eagles and Hillel [2008], Pfueller et al. [2011]. Buckley and Sommer [2001] published a list of factors that facilitate partnerships between the tourist sector and environmental protection stakeholders. This list includes easy access to information and broad-based community involvement. The positive outcomes of these types of endeavors are discussed in a report by Brown and Hay-Edie [2013]. Tourism development is most successful if local governments, tourism promotion agencies, local businesses, and protected natural area management work together in a coherent manner. Together they should define and develop products, target markets, and attract visitors at the right moment and to the right location [Europarc Federation, 2012]. These types of entities interact with national park authorities in a variety of ways. Local authorities provide social services, build economic infrastructure, manage the natural environment, represent the interests of local communities, and they are able to influence the direction of local tourism development [De Lacy et al., 2002]. The extent of collaboration varies depending on country and type of protected area. The issue of collaboration between national park authorities and local governments in Poland was discussed by Hibszer [2013], Iwaszko [2010], Kapera [2012]. This type of research was also conducted in Babia Góra Mountain National Park in Polish mountainous areas by Pawlusiński et al. [2008].

\subsection{Conflict between national parks and local governments with a focus on tourism}

Tourism is a mostly desirable form of economic activity - both from the perspective of local governments and national parks. Yet, it can be difficult for a national park to protect nature and welcome tourists at the same time. Tourism is increasingly believed to be a real means of generating sizable profits that can be used to protect the natural environment of national parks [Hübner et al., 
2014]. A portion of the profits generated by tourism is also used to modernize or built tourist facilities, which helps further develop the sector. Financial issues do affect national parks, their immediate vicinity, and especially areas less frequently visited. There exists a need for a variety of services and new infrastructure investment. The complexity of this problem prompts local communities and local governments to become interested in developing the tourism sector in area national parks. However, different objectives of different entities make collaboration between national parks and local governments in the realm of tourism development difficult. Conflict between national parks and local communities is known to occur across the world. In this context, Pedersen [2002] analyzed both problems and potential solutions. Poncelet [2004] investigated a combination of conflicts and environmental partnerships. The subject of social conflict and national parks in Poland was covered by Królikowska [2007], while Dubel et al. [2013] analyzed this conflict for Nature 2000 areas - also from the perspective of the tourist sector. Tourism-related conflict emerges on three different levels and concerns not only the broadly defined realm of tourist infrastructure, but also tourist traffic itself, and especially its volume and excess concentration at particularly attractive locations. The effective solution of many of these types of problems is very important for national park managers and the politicians who represent stakeholders including local residents. Both tourism and recreation at national parks cannot occur in an uncontrolled manner due to parks' primary objective to protect nature. In some cases, certain tourist and recreational activities cannot be permitted at national parks due to the unique environmental and cultural value of these geographic areas. Hence, it is often the case that the two basic functions of national parks - protection of nature and being open to visitors - remain in conflict with one another. In addition, excess tourist volume represents a threat to the natural environment present in a national park and serves as a potential source of conflict. Conflicts of this type are likely for yet another reason. The principal difficulty associated with the presence of a national park is the limit on new residential construction and expansion of existing homes. The pressure to build new homes and expand existing ones is quite significant in areas near national parks and this yields conflict. Environmental studies associated with proposed zoning laws at the commune level and the provincial level need to be reviewed and approved by the director of each given national park in question in light of the negative effects of home construction on the natural environment. The same applies to environmental and zoning studies for inland marine areas, coastal areas, and special economic areas in the vicinity of national parks and their immediate surroundings. The effect of settlement pressure was investigated for selected national parks in Poland. For example, this problem was found to be quite acute in the case of Kampinoski National Park, located just west of Warsaw. The city is growing dynamically and consuming increasingly large parcels of suburban land. Hence, it is important to study the opinions of all stakeholders in question. In addition. it is important to determine the limits of tourist activity for national parks, which must comply with local and national laws, and 
must factor in the needs of local entities such as businesses, environmental organizations, area residents, and other significant stakeholders.

It is helpful to determine the limits of the impact of tourism and recreation on protected areas, as analyzed by Witkowski et al. [2010]. While the problem of conflict with protected areas and in adjacent areas is rather common, research by Kothari [2008], provides reasons for optimism. Kothari argues that, if current trends continue over the next few decades, there will occur a significant reduction in conflict between people and protected areas, along with an increase in public, including local community, support for not only protected areas, but for conservation across the landscape.

\section{Data and methods}

\section{I. Study area}

There is a total of 23 national parks in Poland, which occupy about one percent of the area of the country. National parks in Poland vary substantially in terms of surface area - ranging from about 2,100 hectares (Ojcowski National Park) to close to 60,000 hectares (Biebrzański National Park). Table 1 shows basic data for national parks in Poland - accurate as of late 2014.

Kendall's tau correlation $(\tau)$ was utilized to analyze ordered data in order to show that park surface area is linked with the number of counties $(\tau=0.392$, $\mathrm{p}=0.019)$, while the correlation with the number of communes is only close to statistical significance $(\tau=0.279, \mathrm{p}=0.078)$. Most national parks in Poland are found in the southern part of the country - in mountainous areas characterized by the highest environmental and landscape value in Poland. The largest number of national parks is found in Małopolskie Province (5). National parks in Poland include parts of at least two communes - and can include parts of as many as 14 communes. More than one million people currently live in communes featuring at least a part of a national park. Most residents of these communes live very close to their area national park. The primary mission of each national park is the protection of the natural environment. National parks also play a role in scientific research, school teaching, college teaching, and general societal education. Special events that facilitate the education of national park visitors include readings of works, thematic contests, youth meetings, film viewings, workshops, and other thematic activities. National parks are to be made available to the general public for tourist and recreational purposes in a manner that does not negatively affect their natural environment. In the early 1960 s, the number of park visitors ranged from four to five million per year, following an increasing pattern, although there were only ten national parks at the time [Partyka, 2010]. In current times, about 11 million tourists visit 23 national parks in Poland every year. The largest number of visitors is recorded at national parks in mountain areas: Tatra National Park, 


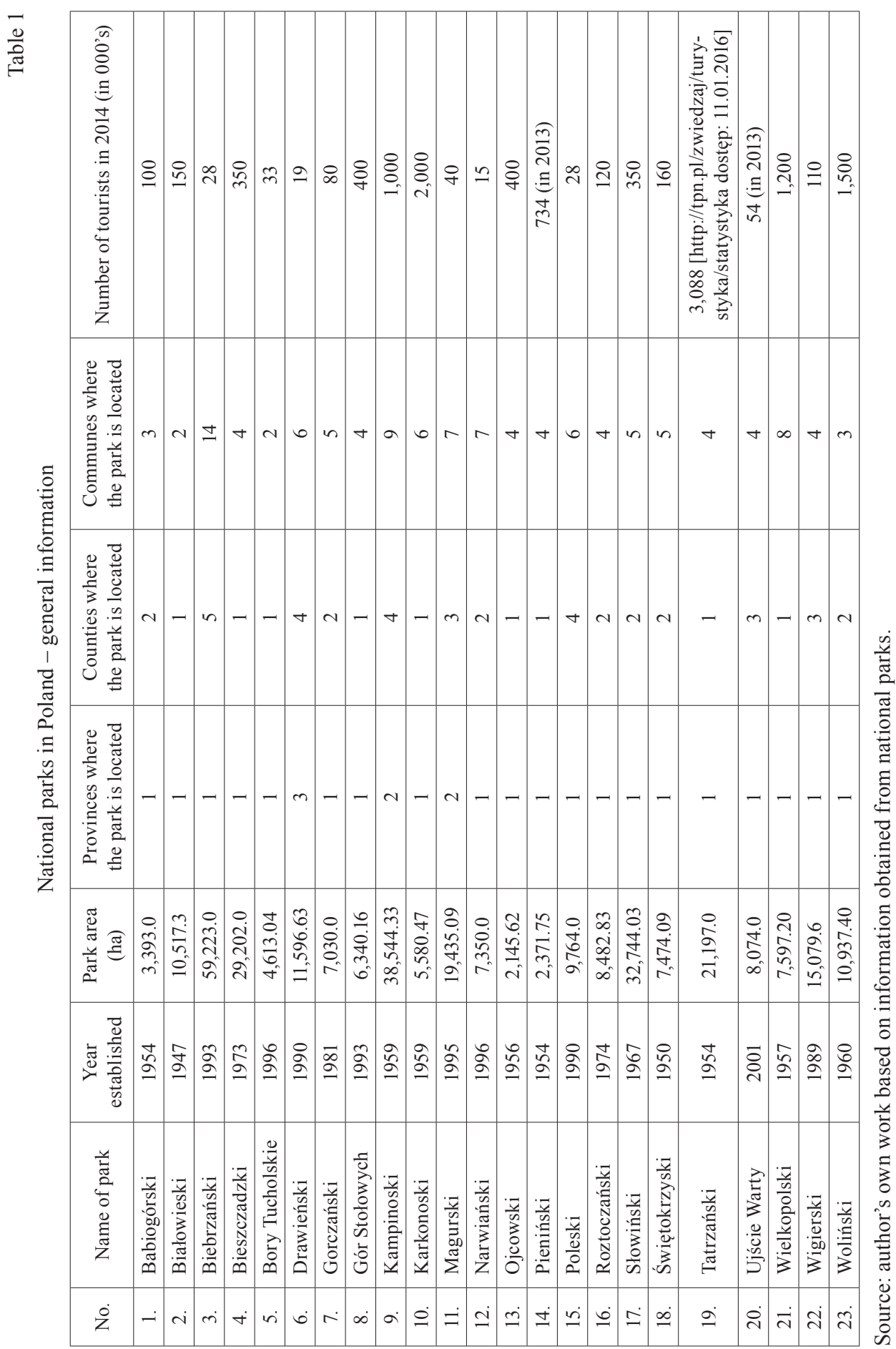


Karkonoski National Park, by the sea - Wolin National Park, and in suburban areas (Kampinos National Park, Wielkopolska National Park). The number of visitors ranges from less than 10,000 to almost three million per year. Research has shown that there does not exist a relationship between park surface area and the number of visitors. At the same time, there appears to be a relationship between park surface area and the number of visitors per hectare; i.e. the larger the park, the fewer the visitors per hectare. Most national parks in Poland are prepared to handle large numbers of visitors. Most national parks feature lodges, summer homes, RV parks, and campgrounds. More than 3,600 km of tourist trails are available to visitors (Table 2).

Table 2

Basic information on tourist infrastructure in national parks in Poland in 2015

\begin{tabular}{|c|c|c|c|c|c|c|c|c|c|c|c|c|}
\hline 吾 & $\begin{array}{l}\frac{n}{\mathscr{E}} \\
\frac{\pi}{\mathscr{W}}\end{array}$ & 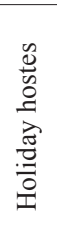 & 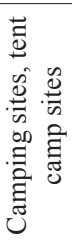 & 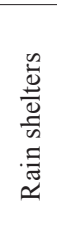 & 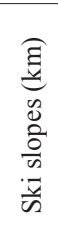 & 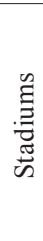 & 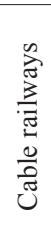 & $\stackrel{\mathscr{S}}{\leftrightarrows}$ & 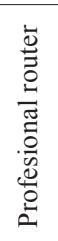 & 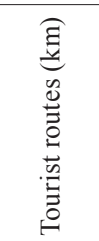 & 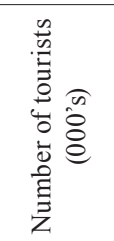 & 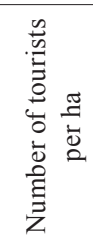 \\
\hline $\begin{array}{c}\text { National } \\
\text { parks }\end{array}$ & 26 & 9 & 31 & 374 & 93.1 & 4 & 11 & 13 & 3 & $3,75.39$ & $10,937.2$ & $1,582.3$ \\
\hline
\end{tabular}

Source: author's own work based on GUS data for 2015.

\subsection{Data collection}

The paper focuses on linkages between national parks, as represented by their management, and local government at the commune level represented by local officials. It attempts to answer the following question: How do national parks view their relationship with commune governments functioning in their area in the context of the development of the tourist sector? The purpose of the paper is to analyze the extent of joint efforts between national parks and local governments in the area of tourism development and to assess the quality of this form of collaboration. The research procedure used in the study is based on the following five stages: (1) review of the Polish research literature, (2) review of the nonPolish research literature, (3) preparation of the survey questionnaire - the main research tool, (4) distribution of the questionnaire to all national parks in Poland, (5) collection of the questionnaires and analysis of survey data. The survey was conducted in 2015 and consisted of three basic sections. Section One consisted of general information on each national park. Section Two consisted of information on tourist infrastructure. Section Three included 23 questions on national park collaboration with local government. National park officials were given the 
opportunity to assess the quality of their joint efforts with local government officials via three different responses: (1) good, (2) bad, (3) average. All the collected data were analyzed using a variety of statistical indicators and conclusions were drawn based on these indicators.

\subsection{Limitations}

The study covers all 23 national parks in Poland. In order to provide a deeper analysis of local governments collaboration with national park authorities, it will be necessary to conduct this type of study in the communal offices.

\section{Results}

More than half national park officials rated joint efforts as average quality. Fewer officials rated these interactions as good (Table 3). Collaboration between national park officials and local government officials can occur in the following areas: (1) promotional work, (2) publishing work, (3) formulation of local land management plans, (4) formulation of social and economic development plans. Another area of collaboration is tourism development including the establishment of tourist trails and other elements of tourist infrastructure in national parks. Collaboration, especially at the commune level, is also readily apparent in the area of education, environmental analysis, park project management, and financing of park facility renovation projects. However, work efforts typically associated with environmental protection were less often mentioned in the context of national park and local government collaboration.

Table 3

Assessment of collaboration between national parks and local governments

\begin{tabular}{|l|c|c|}
\hline & Responses & Percentages \\
\hline Good & 11 & 47.8 \\
\hline Average & 12 & 52.2 \\
\hline Total & 23 & 100.0 \\
\hline
\end{tabular}

Source: author's own work.

Joint decisions in the area of tourism development made by national park managers and local government officials were noted at 20 of 23 national parks in Poland. Collaborative decision-making was not observed at three national parks (Table 4). 
Table 4

Responses to the question: Do national parks make joint decisions with local governments in the area of tourism development?

\begin{tabular}{|c|c|c|}
\hline & Responses & Percentages \\
\hline No & 3 & 13.0 \\
\hline Yes & 20 & 87.0 \\
\hline Total & 23 & 100.0 \\
\hline
\end{tabular}

Source: author's own work.

The largest number of joint decisions in the area of tourism development at national parks in Poland were made with respect to promotional efforts including the publishing of brochures, provision of information in other forms, organization of special events, and other campaigns. The next top issue subject to joint decision-making was associated with tourist infrastructure, especially the establishment and maintenance of tourist trails. National parks also assist local communities in the areas of education and consulting and work with local governments in the area of planning. Two national parks were also found to be working with local governments to support agro-tourism. In rare cases, national park representatives noted a role in the joint creation of local tourist offerings and access to national park land for the purpose of tourism, recreation, and sports. Eighteen national parks (78\%) make joint decisions with local governments with respect to the area of promotion. Eleven parks participate in tourist fairs. Thirteen parks (56.5\%) issue folders and guidebooks. Seven parks (30.4\%) advertise in newspapers as well as on the radio and on television. Nine parks (39.1\%) advertise on the Internet. Sixteen parks (approx. 70\%) participate in joint promotional events and contests. Finally, thirteen parks (56.5\%) participate in exhibitions. The vast majority of national parks and their local governments participate in educational efforts associated with environmental protection and tourism in areas featuring national parks (19 parks or $82.6 \%$ ). In addition, more than $30 \%$ of national parks pursue joint social initiatives. Slightly more than half the studied national parks admitted to possessing a collaboration agreement with local governments. The vast majority of national parks in Poland (91.3\%) take part in European Union financing programs. Eighteen national parks pursue European Union funds for the purpose of tourism-related projects. Fourteen national parks (61\%) indicated some type of conflict with local governments. Six parks did not indicate any conflict with local governments (Table 5). Three parks did not respond to this question. The distribution of park responses with respect to conflict with local communities was similar: yes -13 responses, no -8 responses, 2 - lack of response. 
Table 5

Responses to the question: Do you indicate any type of conflict with local government?

\begin{tabular}{|l|c|c|}
\hline & Responses & Percentages \\
\hline No response & 3 & 13 \\
No & 6 & 26 \\
\hline Yes & 14 & 60 \\
\hline Total & 23 & 100 \\
\hline
\end{tabular}

Source: author's own work.

In addition, conflicts occurred less frequently in cases where joint promotional efforts were made by national parks and local stakeholders $(\mathrm{z}=2.001, \mathrm{p}=0.045)$ (Figure 1).

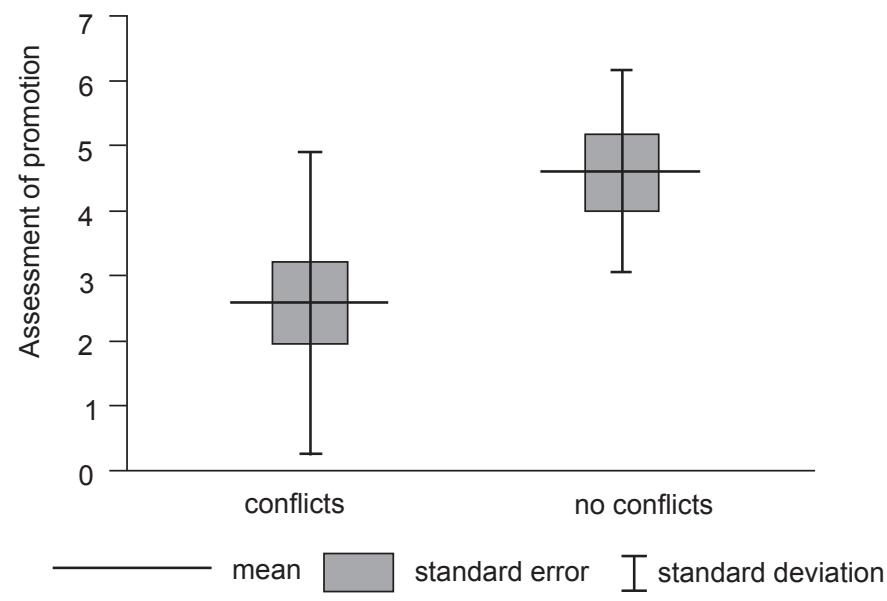

Figure 1. Assessment of promotion

Source: author's own work.

National park representatives listed the following ways in which conflicts with local officials could be resolved: (1) additional training of local officials, (2) steps to improve understanding of relevant issues, (3) finding ways for local communities to benefit from being located in the vicinity of a national park. Other key issues raised in the survey process were the following:

- the need to spark the interest of local governments in environmental protection and the need to clarify and emphasize environmental protection requirements already written into law,

- joint acquisition of European Union funding,

- joint promotional efforts affecting entire communes and not just national parks, 
- organization of meetings, generation of dialogue, formulation of communications strategy, streamlining of information flow,

- establishment of special team to resolve smaller conflicts and solve larger problems.

\section{Discussion}

Representatives of national parks in Poland rated the quality of their collaboration with local government officials as either good or average. This finding confirms information found in the document [NIK, 2014]. This document states that the directors of all 23 national parks in Poland collaborate with local governments and various other key organizations. The level of collaboration varies by national park, depending on local needs. National park directors often sign collaboration agreements with local communes, commune unions, associations, ecological organizations, tourist organizations, teaching institutions, and research institutions. The basic outcome of this collaboration has been the organization of joint ventures designed to protect the natural environment, educate the general public, and resolve conflicts [NIK, 2014]. Hibszer [2013] analyzed the quality of collaboration at the commune level. The relationship between national parks and local governments was judged to be good for 14 national parks, very good for 6 national parks, and average for 3 national parks [Hibszer, 2013]. The relationship was also analyzed by Hibszer and Markowski [2010] for the case of residents in the close vicinity of Kampinoski National Park, which is located close to Poland's capital city of Warsaw. Research conducted among school students as well as adults shows that almost half of school students rate the national park and local government relationship as good or very good. Less than $10 \%$ believe that the relationship can be described as bad or very bad. The remaining school students did not express an opinion on this issue. In the case of adult survey participants, the ratio of positive to negative opinions on the national park versus local government relationship was 2:1 [Hibszer, Markowski, 2010]. Collaboration in the area of tourism concerns mostly promotional efforts and various forms of tourist infrastructure development. This type of research was also conducted in Babia Góra Mountain National Park and has shown that in order to create a local partnership for tourism, the most important issue is to achieve agreement and to establish collaboration between local authorities and the administration of Babia Góra National Park. Collaboration between concerned parties is the main condition for success in the following four areas: tourism promotion, development and implementation of an integrated tourist information system, decentralization and monitoring of tourism, limits on the negative impacts of tourism [Pawlusiński et al., 2008]. Other research studies have also shown this to be the case [Hibszer, Markowski, 2010]. More than 200 adult survey participants were asked to identify 3 characteristics - out of a group of 10 - that would best describe national parks. The top three responses were: (1) valuable natural landscape area, (2) opportunity 
to promote a region, (3) research area for scientists. In addition, 64 participants noted that the presence of a national park represents an opportunity to obtain special funding from the European Union [Hibszer, Markowski, 2010]. The vast majority of national park representatives admitted to applying for and obtaining funds from the European Union. Educational programs are another area of national park collaboration with local governments. National park representatives have suggested more training for local government officials to make them more aware of national park needs. However, according to Hibszer [2013], local governments rate their level of knowledge about national parks as good (66\% of survey participants) or very good (almost $20 \%$ of survey participants). Different objectives of different entities make collaboration between national parks and local governments in the realm of tourism development difficult. Various forms of conflict with local government were identified by $61 \%$ of national park directors, which is borne out by other data as well. In the period 2010-2012, Poland's Ministry of the Environment received 38 complaints linked with national parks -28 of which were filed by private individuals and 2 were filed by local governments [Kutyła, 2013]. The complaints focused on real estate owned by national parks, fees charged by parks for driving on park property, flooding of agricultural land located within national parks, and the privatization of the Polish Cableways Company [Kutyła, 2013]. Hence, conflict situations do require a broader perspective. The solution of problems in this case requires not only financial resources in the form of trail modifications and the rerouting of tourists to attractive landscape parks, but also changes in awareness via the environmental education of tourists. The latter is well served by existing educational centers functioning at national parks in Poland. Many of these educational centers are undergoing renovation and will be even more effective in the near future [Partyka, 2010]. Research has shown the need for dialogue between various national park stakeholders. It is often the case that conflict can be avoided by fostering proper communication, optimal flow of information, societal participation, consultation with key stakeholders, and early reaction to feedback [Dubel et al., 2013]. In situations where conflicts cannot be resolved via reasonable discussion at the negotiating table, there exist specific legal instruments that can be used to end a stalemate. These include laws and regulations as well as various tourist traffic indicators that help assess the level of infrastructure needed in conjunction with the need to maintain a level of development that does not harm the natural environment or a designated cultural area [Szczechowicz, 2010]. The solution to a problem can start at the planning stage in the tourism development process. The inclusion of local communities is a crucial part of the planning and management process [Pedersen, 2002; Eagles, McCool, 2002]. De Lacy et al. [2002] proposed the socalled 5Ps for sustainable destination planning and development and management: (1) policy and planning, (2) predictive modeling, (3) performance monitoring, (4) performance improvement, and (5) performance reporting. Key issues include writing of better laws, more time, more human resources, more financial resources, and the willingness to negotiate in good faith. Mutual trust between key institutions and societal stakeholders is established via public consultation, 
park information campaigns, mutual respect, and the release of trustworthy information. Increased mutual trust is a means of increasing societal participation in the planning and management process [Dubel et al., 2013].

\section{Conclusion}

National parks function to protect the natural environment, but also pursue other goals such as the development of tourism. At the same time, national parks must consider the requirements of their parent communes and their local governments. The principles of regional sustainable development demand that both tourists and national park area residents care for the park's natural environment. In addition, benefits associated with the presence of a national park are to be available to both tourists and park area residents. National park authorities and local government officials are interested in the development of tourism in and near national parks. This helps explain why the study has shown that the vast majority of national parks in Poland work with local governments to foster the development of national park tourism. Most of these efforts concern park promotion and the construction and maintenance of tourist infrastructure. Despite the predominantly good or average ratings of national park and local government collaboration, more than $60 \%$ of national parks in Poland experience conflicts with local area stakeholders. The solution to this problem proposed by national park officials is additional training for local government officials in the area of national park needs and the needs of the tourist sector. Other means of improving the national park and local government relationship in the key area of tourism development include greater inclusion in the planning process, optimization of the planning process itself, and additional improvements in the way in which stakeholders communicate with national parks.

\section{References}

Bramwell B., Lane B. (eds.) (2000), Tourism Collaboration and Partnerships Politics, Practice and Sustainability, Chanel View Publications, Sydney.

Brown J., Hay-Edie T. (2013), COMPACT: Engaging Local Communities in the Stewardship of World Heritage, UNDP, New York.

Buckley R.C. (2011), Tourism and Environment, "Annual Review of Environment and Resources", 36, pp. 397-416.

Buckley R.C., Sommer M. (2001), Tourism and Protected Areas, Partnership in Principle and Practice, CRC for Sustainable Tourism, Gold Coast.

De Lacy T., Battig B., Moore S., Noakes S. (2002), Public/Private Partnerships for Sustainable Tourism: Delivering a Sustainability Strategy for Tourism Destinations, CRC for Sustainable Tourism, Gold Coast. 
Dubel A., Jamontt-Skotis M., Królikowska K., Dubel K., Czapski M. (2013), Metody rozwiazywania konfliktów ekologicznych na obszarach Natura 2000, Stowarzyszenie Centrum Rozwiązań Systemowych Wrocław-Kraków, [dok. elektr.] http://natura2000.crs.org.pl/ partycypacja/pliki/file/publikacja_PINAT.pdf [dostęp: 11.01.2016].

Eagles P.F.J. (2009), Governance of Recreation and Tourism Partnership in Park and Protected Areas, "Journal of Sustainable Tourism", 17(2), pp. 231-248.

Eagles P., Hillel O. (2008), Improving Protected Area Finance through Tourism. Paper presented to the Second meeting of the Ad Hoc Open-ended Working Group on Protected Areas (WGPA-2) - Rome, Italy, February 11 - 15 2008, in Preparation for the Ninth Meeting of the Conference of the Parties to the Convention on Biological Diversity (COP-9) Bonn, Germany, [dok. elektr.] http://ahs.uwaterloo.ca/ eagles/documents/EaglesandHillelArticleonEconomicsandFinanceofTourisminProtectedAreas.pdf [dostęp: 11.01.2016].

Eagles P.F.J., McCool S.F. (2002), Tourism in National Parks and Protected Areas: Planning and Management, CABI, New York.

Europarc Federation (2012), Practical, Profitable, Protected: A Starter Guide to Developing Sustainable Tourism in Protected Areas. Latvia, European Centre for Eco and Agro Tourism in Partnership with the Europarc Federation.

GUS (2016), Ochrona środowiska 2016, Warszawa.

Hibszer A. (2013), Parki narodowe w świadomości i działaniach społeczności lokalnych, Uniwersytet Śląski, Katowice, [dok. elektr.] http://ptg.wnoz.us.edu.pl/doc/HIBSZER.pdf [dostęp: 11.01.2016].

Hibszer A., Markowski M. (2010), Czy możliwe jest ograniczenie presji urbanizacyjnej głównego zagrożenia urbanizacyjnego Kampinoskiego Parku Narodowego? Is it possible the limitation of urbanization pressure - the main anthropogenic threat to the Kampinos National Park?, "Prądnik. Prace i Materiały Muzeum im. Prof. Władysława Szafera”, 20, pp. 211-224.

Hübner A., Phong L.T., Chậu T.S.H. (2014), Good Governance and Tourism Development in Protected Areas: The Case of Phong Nha-Ke Bang National Park, Central Vietnam, "Koedoe", 56(2).

Iwaszko K. (2010), Turystyka na obrzeżach Narwiańskiego Parku Narodowego. Tourism at the Narew National Park Outskirts, "Architecturae et Artibus", Vol. 2, No. 3(5), pp. 27-35.

Kapera I. (2012), Tourism and recreation as areas of collaboration between local governments and Gorce National Park, "Bulletin of Geography. Socio-economic series", 17, pp. 67-75.

Kapoor I. (2001), Towards Participatory Environmental Management?, "Journal of Environmental Management", 63, pp. 269-279.

Kothari A. (2008), Protected Areas and People: The Future of the Past, "Parks", 17(2), pp. 23-34 .

Królikowska K. (2007), Konflikty społeczne w polskich parkach narodowych, Wydawnictwo Impuls, Kraków.

Kutyła W. (2013), Wystapienie pokontrolne. Funkcjonowanie parków narodowych, Wiceprezes Najwyższej Izby Kontroli Wojciech Kutyła, Warszawa, [dok. elektr.] www.mos.gov. pl/g2/big/.../786610ccb0fdc654379db47a174e638c.pdf [dostęp: 11.01.2016].

Leung Y.F., Spenceley A., Hvenegaard G., Buckley R. (eds.) (2014), Tourism and Visitor Management in Protected Areas Guidelines for Sustainability. Best Practice Protected Area Guidelines, IUCN World Park Congress, Sydney. 
NIK (2014), Funkcjonowanie parków narodowych. Informacja o wynikach kontroli, Najwyższa Izba Kontroli, Warszawa, [dok. elektr.] https:/www.nik.gov.pl/kontrole/wyniki-kontroli-nik/pobierz,ksi p_13_123... [dostęp: 11.01.2016].

Partyka J. (2010), Ruch turystyczny w polskich parkach narodowych, „Folia Turistica”, 22, pp. $9-25$.

Pawlusiński R., Mika M., Faracik R. (2008), Regional Tourism Management and Development Plan in the Babia Gora Region, Stowarzyszenie Przyjaciół Babiej Góry (Friends of Babia Góra) \& Authors, Kraków.

Pedersen A. (2002), Managing Tourism at World Heritage Sites: A Practical Manual for World Heritage Site Managers, World Heritage Manuals, Paris.

Pfueller S.L., Lee D., Laing J. (2011), Tourism Partnerships in Protected Areas: Exploring Contributions to Sustainability, "Environmental Management", 48(4), pp. 734-749.

Poncelet E.C. (2004), Partnering for the environment: multistakeholder collaboration in a changing world, Rowman \& Littlefield, Oxford.

Saporiti N. (2006), Managing National Parks: How Public-Private Partnerships Can Aid Conservation, World Bank, Washington.

Selin S. (1999), Developing a typology of sustainable tourism partnerships, "Journal of Sustainable Tourism", 7(3\&4), pp. 260-273.

STCRC (2008), Tourism and Protected Area Management, Australia: Sustainable Tourism Cooperative Research Centre CRC, [dok. elektr.] http://www.sustainabletourismonline.com/awms/Upload/Resource/CRC\%208021\%20\%28PAM\%29Final\%20version\%20 \%281\%29.pdf [dostęp: 11.01.2016].

Szczechowicz B. (2010), Zrównoważony rozwój obszarów recepcji turystycznej-grupy interesów i źródła konfliktów, "Folia Turistica”, 22, pp. 167-183.

The Nature Conservation Act of 16 April 2004. Journal of Laws - Republic of Poland of 2015, item 1651, http://prawo.legeo.pl/prawo/ustawa-z-dnia-16-kwietnia-2004-r-o-ochronie-przyrody/ [dostęp: 11.01.2016].

Witkowski Z., Adamski P., Mroczka A., Ciapała Sz. (2010), Granice ingerencji turystyki i rekreacji na obszarach ladowych parków narodowych i rezerwatów przyrody. Limits of tourism and recreation interference in land areas of national parks and nature reserves, "Prądnik. Prace i Materiały Muzeum im. Prof. Władysława Szafera", 20, pp. 427-444.

Zawilińska B., Mika M. (2013), National Parks and Local Development in Poland: A Municipal Perspective, "Human Geographies - Journal of Studies and research in Human Geography”, 7(1), pp. 43-52.

http://tpn.pl/zwiedzaj/turystyka/statystyka [dostęp: 11.01.2016]. 